\title{
The Duty of Fair Representation
}

\author{
Archibald Cox
}

Follow this and additional works at: https://digitalcommons.law.villanova.edu/vlr

Part of the Labor and Employment Law Commons

\section{Recommended Citation}

Archibald Cox, The Duty of Fair Representation, 2 Vill. L. Rev. 151 (1957).

Available at: https://digitalcommons.law.villanova.edu/vlr/vol2/iss2/1

This Article is brought to you for free and open access by Villanova University Charles Widger School of Law Digital Repository. It has been accepted for inclusion in Villanova Law Review by an authorized editor of Villanova University Charles Widger School of Law Digital Repository. 


\section{Villanova Law Review}

VoLUME 2

JANUARY, 1957

NUMBER 2

\section{THE DUTY OF FAIR REPRESENTATION.}

\section{Archibald Cox $\dagger$}

$\mathrm{T}^{\mathrm{H}}$

HE REPRESENTATIVE designated by a majority of the employees in an appropriate bargaining unit has a duty to bargain fairly in behalf of all the employees, union members and nonmembers, and without hostile discrimination among them. The employees' correlative right to fair representation is one of the three important safeguards the law affords individual workers against abuse of power by a union. The other two are the limited protection accorded to the individual's interests in union membership and job opportunities. This paper discusses the origin of the duty of fair representation, its scope and beneficiaries, the standards of fairness, and the forums and remedies for violation.

I.

Origin of the Duty.

The national labor policy vests great power in the bargaining representative. The National Labor Relations Act, section 9, provides:

"Representatives designated or selected for the purposes of collective bargaining by the majority of the employees in a unit appropriate for such purposes, shall be the exclusive representative of all the employees in such unit. . . ."1

The Railway Labor Act contains similar provisions. ${ }^{2}$ A minority union may not bargain ${ }^{3}$ or present grievances. ${ }^{4}$ Individual contracts

$\dagger$ Professor of Law, Harvard Law School. A.B. 1934, LL.B. 1937, Harvard University.

1. National Labor Relations Act $\$ 9$ (a), 61 STAT. 143 (1947), 29 U.S.C. $\$ 159$ (a) (1952). (Emphasis added).

2. Railway Labor Act $\$ 2$ (para. 4), 48 STAT. 1187 (1934), 45 U.S.C. $\$ 152$ (para. 4) (1952).

3. Majority rule carries the clear implication "that employers shall not interfere with the practical application of the right of employees to bargain through chosen representatives by bargaining with individuals or minority groups in their own behalf, after representatives have been picked by the majority to represent all." S. REP. No. 573, 74th Cong., 1st Sess. 13 (1935).

4. Hughes Tool Co. v. NLRB, 147 F.2d 69 (5th Cir. 1945) ; Federal Tel. and Radio Co., 107 N.L.R.B. 649 (1953); see Miami Copper Co., 92 N.L.R.B. 322, 323, 334-38 (1950). Contra, Douds v. Local 1250, Retail Wholesale Dep't Store Union, CIO, 173 F.2d 764 (2d Cir. 1949), 63 Harv. L. Rev. 361. 
do not excuse the employer from bargaining with the majority representative, ${ }^{5}$ nor are they effective to waive rights under a collective agreement. $^{6}$ The employer may not change wages or conditions of employment unilaterally without the assent of the union unless an impasse in collective bargaining has been reached. ${ }^{7}$ The employer is also forbidden to negotiate terms of employment with individual employees-even a numerical majority-so long as they have a bargaining representative. ${ }^{8}$ Thus, so far as individual employees are concerned, collective bargaining resembles the legislative process of a state or municipality. Terms and conditions of employment can be arranged only by the union which has the assent of a majority of the workers, and the rules written into the collective agreement become the law of the plant binding both majority and dissenters.

The possession of such power invites abuse. In Steele v. Louisville \& Nashville R.R. ${ }^{9}$ it appeared that the Brotherhood of Locomotive Firemen and Enginemen was designated under the Railway Labor Act as the bargaining representative of firemen employed by the L. \& N. The L. \& N. employed both white and Negro firemen but the whites were a majority and Negroes were excluded from the union. In 1941 the union negotiated a seniority agreement which gave preference to white firemen in bidding for vacancies and also in making layoffs. A Negro who lost sixteen days' work and then was forced to take a less desirable job by the operation of this provision brought suit against the carrier and the union seeking injunctive and declaratory relief. The state courts dismissed the bill of complaint but on certiorari the Supreme Court held that the bill stated a cause of action for breach of the bargaining representative's duty "to exercise fairly the power conferred upon it in behalf of all those for whom it acts, without hostile discrimination against them." 10

Out of the instinctive Anglo-American distrust for unlimited power grew the "principle of general application that the exercise of a granted power to act in behalf of others involves the assumption toward them of a duty to exercise the power in their interest and

5. J.I. Case Co. v. NLRB, 321 U.S. 332 (1944).

6. Order of Railroad Telegraphers v. Railway Express Agency, Inc., 321 U.S. 342 (1944).

7. NLRB v. Crompton Highland Mills Co., 337 U.S. 217 (1949); May Dep't Stores Co. v. NLRB, 326 U.S. 376 (1945). Perhaps the generalization should be qualified to permit unilateral action in cases where an immediate decision is imperative or the employer has no reason to suppose that the union wishes to participate. The entire subject of unilateral action is discussed in Bowman, An Employer's Unilateral Action - An Unfair Labor Practice? 9 VAND. L. Rev. 487 (1956).

8. Medo Photo Supply Co. v. NLRB, 321 U.S. 678 (1944).

9. 323 U.S. 192 (1944).

10. Id. at 203. 
behalf. . . ." 11 Since the Railway Labor Act made the union the representative of the entire "craft or class," the fair interpretation of the statutory language, read in the light of common law traditions, was that "the organization chosen to represent a craft is to represent all its members, the minority as well as the majority, and it is to act for and not against those whom it represents." ${ }^{12}$ By thus fusing common law and legislation the opinion created a new duty, and thereby supplied the necessary counterpoise to majority rule. All unions are subject to the duty which act as the representatives of a craft or class of employees under the Railway Labor Act. ${ }^{13}$

The bargaining representatives of employees covered by the National Labor Relations Act are also subject to the duty of fair representation. Wallace Corp. $v . N L R B,{ }^{14}$ fixed the rule for "a bargaining agent selected under the terms of the act" on the same day that the Steele case was decided, but until recently there was grave uncertainty as to whether the same obligation rested upon a union which negotiated collective agreements solely by virtue of its economic strength or voluntary designation by all the employees in the unit. Mr. Chief Justice Stone had said that "so long as a labor union assumes to act as the statutory representative . . . it cannot rightly refuse to perform the duty, which is inseparable from the power of representation conferred upon it. . . "15 The sentence seems to imply that there is no duty if the union chooses not to act as the statutory representative. In the former case the union can be said to accept the statutory power cum onere. In the latter case the logic breaks down for the Wagner Act did not regulate the internal affairs or bargaining practices of labor organizations and there is no specific evidence that the Taft-Hartley amendments were intended to change the rule. But even if it be conceded that the amendments weakened the argument to some extent by imposing duties on labor organizations without regard to their acquiescence or dissent, it was still possible to answer that "the act was directed primarily to the prevention of unfair labor practices in order to open the way for free collective bargaining rather than to the regulation of the course of such bargaining and the settlement of disputes." ${ }^{16}$ On this ground, also, it was

11. Id. at 202 .

12.Ibid.

13. Brotherhood of Railroad Trainmen v. Howard, 343 U.S. 768 (1952), makes it plain that the duty is not affected by the absence of certification as the bargaining representative.

14. 323 U.S. $248,255-56$ (1944).

15. 323 U.S. at 204 .

16. Williams v. Yellow Cab Co., 200 F.2d 302, 306 (3d Cir. 1952), cert. denied, 346 U.S. 840 (1953). 
possible to distinguish the Supreme Court decisions enforcing a duty of fair representation against the unions which acted for employees covered by the Railway Labor Act.

In Syres v. Local 23, Oil Workers International Union, ${ }^{17}$ the complaint, which was brought in a district court of the United States, alleged that there were two Oil Workers' locals at a Gulf Oil refinery, the larger being made up of white employees, the smaller of colored. Plaintiffs were all members of the colored local. After an election the locals were jointly certified as the bargaining representative. They designated a negotiating committee whose members were white. The committee negotiated a contract with Gulf which provided:

"Promotions, demotions, lay-offs, bidding, and other applications of seniority shall be made separately by division-i.e., Labor Division and Operating-Mechanical Division."

When the contract took effect, the better paid jobs were in the Operating-Mechanical Division and were held by whites. The poorer jobs were in the Labor Division, which was made up of Negroes. Thus, the superficially innocent clause establishing divisional seniority was in fact a method of racial discrimination.

Since there was no diversity of citizenship, federal jurisdiction depended upon plaintiffs' showing that the cause of action arose under the laws of the United States because the defendant union violated a duty of fair representation imposed by the NLRA. The district court dismissed the bill for want of jurisdiction. The court of appeals affirmed the dismissal. The opinion makes a good deal of the fact that the dispute concerned contracts relating to seniority rather than the interpretation of the NLRA, but the case seems to have been decided on the ground that no federal law was drawn in question because plaintiffs were all members of the union and had, therefore, agreed that it should represent them.

"In exercising its powers to bargain collectively for its members as in all its other activities on their behalf a labor union acts, through its authorized officers, as agent of the entire membership within the authority conferred by its constitution and bylaws. In exercising these bargaining powers the labor union has the corresponding duty of an agent to represent all its members fairly, in good faith and without discrimination. This duty, however, being one imposed by the law of the state in which the union operates, cannot be made the basis for invoking federal jurisdic-

17. 350 U.S. 892, reversing 223 F.2d 739 (5th Cir. 1955). 
tion under section 1331, even though it might well form the basis for action in the state courts." 18

Judge Rives, dissenting, argued that the NLRA enters into the making of a collective agreement and provides sanctions for its enforcement without regard to whether the employees are members of the union. He also pointed out that a union's power under the statute, with or without its consent, is greater than it ordinarily achieves by the voluntary authorization of its members.

"Without the statutory provision, a person might be a member of a local labor union and still retain the right to speak for himself or to have others speak for him as to some of the conditions of his employment. The statute takes away any such right and constitutes the representative designated or selected for purposes of collective bargaining the exclusive representative of all the employees. A member of a local union who finds himself in the minority in the selection of such a representative, or in the selection of the workmen's committee to act for such representative, is almost, if not quite, as powerless to protect himself as is a nonunion member. I can see no valid distinction in the protection afforded by the law between persons who are not members of any union and persons who are minority members of the locals composing the bargaining representative." 19

On plaintiffs' petition for certiorari the Supreme Court granted the writ and simultaneously reversed the judgment, without receiving briefs or hearing argument on the merits. Although there was no opinion, save the bare citation of Steele $v$. Louisville $\mathcal{E}$ N.R.R. and subsequent cases, ${ }^{20}$ it seems safe to conclude the justices agreed with Judge Rives's reasoning.

Every union representing employees in businesses affecting commerce is, therefore, subject to a duty of fair representation, imposed by the NLRA, without regard to whether the complaining employees have had the union imposed upon them by force of the statute or have designated it by voluntary membership. ${ }^{21}$

18. 223 F.2d at 742, quoting Williams v. Yellow Cab Co., 200 F.2d 302, 305 (3d Cir. 1952), cert. denied, 346 U.S. 840 (1953).

19. 223 F.2d at 746.

20. 350 U.S. 892.

21. For discussion of whether breach of the duty is an unfair labor practice see pp. 173, 174 infra. This article does not consider two subjects closely related to the duty of fair representation. One is the common-law duty of a union to those who have conferred authority upon it to represent them under ordinary agency principles. It would seem that the federal law probably pre-empts the field and excludes state courts from enforcing any common-law duty against representatives under the NLRA. The other omitted topic is the employees' right to complain about an unjustifiable interference with their employment or prospective employment under the theory of James v. Marinship Corp., 25 Cal.2d 721, 155 P.2d 329 (1944). 
II.

Scope of the Duty.

The duty of fair representation extends to all phases of collective bargaining. It binds the union in negotiating collective agreements ${ }^{22}$ and in handling grievances. ${ }^{23}$ It is violated by hostile discrimination or other forms of unfairness in arranging terms and conditions of employment without the formality of a contract or grievance. In Dillard v. Chesapeake \& $O$. Ry. ${ }^{24}$ for example, a group of Negro laborers employed by the $C$. \& O. sought equal job opportunities by complaining of a practice under which only white laborers were promoted to better paying, skilled positions even though the Negro employees were as well qualified and had greater seniority. Their complaint against the C. \& O. and the bargaining representative alleged that formerly all qualified laborers had been promoted according to seniority but that this policy was abandoned in favor of racial discrimination largely because of the opposition and activities of the union. In holding that the complaint stated a cause of action the Fourth Circuit said :

"It is immaterial that the unions in exerting their power to discriminate against the Negro employees did not do so by entering into a formal bargaining contract. It is the unlawful use of power vested in the unions by the Railway Labor Act which gives rise to the jurisdiction of the court to afford relief, not the particular form which such abuse of power takes." ${ }^{25}$

The last principle, although sound, will be hard to apply in practice. No federal law prohibits racial discrimination by employers. Only a few states have enacted a Fair Employment Practice Act. There must be thousands of mines, mills and factories in which employers have unilaterally adopted practices which discriminate against minority groups in hiring, layoff or promotion. When there is no bargaining representative, the victims have no legal redress. To apply the Steele doctrine whenever a representative was designated would impose on unions the affirmative obligation of making reasonable efforts to

22. E.g., Syres v. Oil Workers International Union, 350 U.S. 892 (1955); Steele v. Louisville and N.R.R., 323 U.S. 192 (1944); Hargrove v. Brotherhood of Locomotive Engineers, 116 F. Supp. 3 (D. D.C. 1953).

23. Hughes Tool Co. v. NLRB, 147 F.2d 69 (5th Cir. 1945) ; Crowell v. Palmer 134 Conn. 502, 58 A.2d 729 (1948); Griffin v. Gulf \& S.I.R.R., 198 Miss. 458, 21 So.2d 814 (1945).

24. 199 F.2d 948 (4th Cir. 1952), on remand, 136 F. Supp. 689 (S.D. W.Va. (1955); accord, Williams v. Central of Georgia R.R., 124 F. Supp. 167 (M.D. Ga. 1954).

25. 199 F.2d at 951. 
abolish racial discrimination. Neither the Railway Labor Act nor the National Labor Relations Act embodies this purpose, desirable as it may be. The union's only obligation, stated colloquially, is to refrain from action which makes individuals and minorities worse off than they would be in its absence. ${ }^{26}$ Since this obligation would be violated by joining in discriminatory practices, the distinction to be drawn is the hazy but familiar line between action and inaction. ${ }^{27}$

III.

\section{BENEFICIARIES.}

Any employee in the bargaining unit may complain of a breach of the duty of fair representation. The union has power to bind every employee in the unit; therefore, there is a duty to act fairly in behalf of everyone. ${ }^{28}$

Collective agreements frequently stipulate the terms on which new employees will be hired or promoted into the bargaining unit. Applicants for such positions have standing to complain of hostile discrimination. ${ }^{29}$ The rule can be reconciled with the statutory language on the theory that the "employees" for whom the union is authorized to bargain include workers seeking positions available within the unit. ${ }^{30}$

Brotherhood of Railroad Trainmen v. Howard, ${ }^{31}$ suggests that the obligation may extend still farther. On the St. Louis-San Francisco Railway two groups of employees performed virtually the same duties: (1) "brakemen," who were represented by the BRT, a labor organization which systematically excluded Negroes, and (2) "train porters," all of whom were Negroes represented by another union. The carrier and BRT negotiated a contract forbidding the carriers to assign train porters to do work "generally recognized as brakeman's duties." Since 95 per cent of a train porter's work met this description, the clause virtually required the carrier to discharge train porters and thereby eliminate Negroes from this class of service. In an action

26. But see Central of Georgia Ry. v. Jones, 229 F.2d 648, 650 (5th Cir. 1956), cert. denied, 77 Sup. Ct. 32, 57, cert. granted, 77 Sup. Ct. 90. In that case Brown, C. J., said in dissenting from the decree on the ground that excessively broad relief was granted: "The Brotherhood had, to be sure, the profound obligation fully and earnestly to bargain to prevent, and, where necessary, remove, discriminations."

27. See also pp. 175-177 infra, where this problem is discussed in connection with the formulation of remedies.

28. Syres v. Oil Workers International Union, 350 U.S. 892 (1955); Steele v. Louisville \& N.R.R., 323 U.S. 192 (1944).

29. Dillard v. Chesapeake \& O. Ry., 199 F.2d 948 (4th Cir. 1952). Contra, Courant v. Photographers of Motion Picture Industry, 176 F.2d 1000 (9th Cir. 1949), cert. denied, 338 U.S. 943 (1950).

30. $C f$. Phelps Dodge Corp. v. NLRB, 313 U.S. 177 (1941).

31. 343 U.S. 768 (1952) ; accord Wood v. Randolph, 209 F.2d 634 (8th Cir. 1954). 
brought by the train porters the Supreme Court rejected the argument that the Steele doctrine was inapplicable because the plaintiffs, unlike Steele, were not members of the bargaining unit represented by BRT.

"The Federal Act thus prohibits bargaining agents it authorizes from using their position and power to destroy colored workers' jobs in order to bestow them upon white workers. . . . Bargaining agents who enjoy the advantages of the Railway Labor Act's provisions must execute their trust without lawless invasions of the rights of other workers. ${ }^{32}$

The sentences just quoted can be explained on three legal theories:

(1) Possibly breach of the duty of fair representation is a tort giving rise to a cause of action in favor of any person whom the union injures by an "unreasonable" exercise of its statutory bargaining power. This would be an unprecedented extension of liability, for the duty is not limited to racial issues. ${ }^{33}$ Even in the latter field it would seem to usurp the legislature's function by imposing the very same obligations on private organizations as bills to protect civil rights and eliminate unfair employment practices.

(2) Justice Black may have been influenced by the argument, presented and rejected in the Steele case, that union action is state action which can be challenged under the fifth and fourteenth amendments whenever legislation is a source of the union's power. ${ }^{34}$ The opinion does not mention that thesis, however, and it seems unlikely that a majority would have concurred in the silent adoption of this sweeping principle.

(3) Probably the Howard case should be limited to its peculiar facts. The problem arose only because bargaining units had been established along racial lines. In substance the BRT was seeking to bring virtually all the work within one bargaining unit composed of men performing work "generally recognized as brakemen's duties." Apparently the train porters were also willing to merge the bargaining units, for they actually sought to become brakemen. Taking the common premise the train porters could fairly be described as employees within the new unit-or at least as applicants for such employmentwho were deprived of jobs because of a contract which required racial discrimination. This analysis would bring them within the class of beneficiaries to whom the bargaining representative has fiduciary obliga-

32. 343 U.S. at 774 .

33. See pp. 159, 160 infra.

34. The argument was based upon the line of cases exemplified by Smith v. Allwright, 321 U.S. 649 (1944); cf. Discrimination by Labor Unions in the Exercise of Statutory Bargaining Powers, 58 HaRv. L. REv. 448 (1945). 
tions under the Steele doctrine, and would make it unnecessary to develop a tort duty or embrace or broaden the concept of state action..$^{35}$

IV.

\section{Violations.}

"Variations in the terms of the contract based on differences relevant to the authorized purposes of the contract in conditions to which they are to be applied, such as differences in seniority, the type of work performed, the skill with which it is performed, are within the scope of the bargaining representation of a craft all of whose members are not identical in their interest or merit," but "discriminations based on race alone are obviously irrelevant and invidious." 36 The doctrine forbids racial discrimination in wage rates, hiring or discharge, ${ }^{37}$ layoffs, ${ }^{38}$ job assignments ${ }^{39}$ and promotions. ${ }^{40}$ Ordinarily discrimination based upon color, creed, or national origin is also unlawful. Such invidious distinctions cannot be salvaged by euphemisms or tricky devices which systematically exclude minorities despite a superficial, formal equality of opportunity. In Salvant $v$. Louisville \& N.R.R., ${ }^{41}$ for example, the court set aside a "forced promotion" rule requiring all locomotive firemen to take and pass examinations for promotion from firemen to engineer and calling for dismissal of those who failed, on the ground that it was a transparent device for bringing about the discharge of elderly Negro firemen.

Despite a few decisions tending to confine the Steele case to instances of racial discrimination, ${ }^{42}$ it is now settled that the right of

35. Cf. The Supreme Court, 1951 Term, 66 Harv. L. Rev. 88, 148-149 (1952).

36. Steele v. Louisville \& N.R.R., 323 U.S. 192, 203 (1944).

37. Rolax v. Atlantic Coast Line R.R., 186 F.2d 473 (4th Cir. 1951) ; Brotherhood of Locomotive Firemen and Enginemen v. Mitchell, 190 F.2d 308 (5th Cir. 1951) ; Salvant v. Louisville \& R.R., 83 F. Supp. 391 (W.D. Ky. 1949).

38. Steele v. Louisville \& N. R.R., 323 U.S. 192 (1944); Tunstall v. Brotherhood of Locomotive Firemen \& Enginemen, 323 U.S. 210 (1944); Griffin v. Gulf and Ship Island R.R., 198 Miss. 458, 21 So.2d 814 (1945).

39. Brotherhood of Railroad Trainmen v. Howard, 343 U.S. 768 (1952; Rolax v. Atlantic Coast Line R.R., 186 F.2d 473 (4th Cir. 1951) ; Central of Georgia Ry. v. Jones, 229 F.2d 648 (5th Cir. 1956), cert. denied, 77 Sup. Ct. 32, 57, cert. granted, 77 Sup. Ct. 90.

40. Syres v. Oil Workers International Union, 350 U.S. 892 (1955); Dillard v. Chesapeake \& O. R.R., 199 F.2d 948 (4th Cir. 1952), on remand, 136 F. Supp. 689 (S.D. W.Va. 1955); $c f$. Haynes v. Union Pacific R.R., 184 F.2d 337 (9th Cir. 1950).

41. 83 F. Supp. 391 (W.D. Ky. 1949) ; cf. Rolax v. Atlantic Coast Line R.R., 186 F.2d 473 (4th Cir. 1951); Mitchell v. Gulf, Mobile \& Ohio R.R., 91 F. Supp. 175, 180-182 (N.D. Ala. 1950), aff'd, 190 F.2d 308 (5th Cir. 1951).

42. E.g., Elder v. New York Central R.R., 152 F.2d 361 (6th Cir. 1945). In Spires v. Southern Ry., 204 F.2d 453 (4th Cir. 1953), the plaintiffs attacked an agreement between the carrier and the bargaining representative which reversed the order 
fair representation protects individuals and minorities against all forms of hostile discrimination or oppression at the hands of the bargaining representative. ${ }^{43}$ It is too early to tell, however, where the courts and administrative agencies will strike the balance between the clains of individuals and minorities to legal protection against fundamental unfairness and the advantages of free collective bargaining and majority rule. The most practicable classification of the precedents is according to the subject of the disputed agreement.

Pension plans and other programs of forced retirement have been attacked for unreasonable discrimination against overage workers, especially on railroad properties, but the courts have uniformly upheld the agreements even though they wiped out extremely valuable "job rights" of senior employees. ${ }^{44}$ On the other hand, an agreement confining overtime work to union members is invalid. ${ }^{45}$ Distinctions based upon age may be reasonable as a man passes sixty-five, whereas differentiations based upon union membership violate the congressional policy of preserving the full freedom of employees in choosing bargaining representatives. In the absence of bad faith there is no unfairness in computing vacation pay on the basis of earnings during the preceding calendar year even though the base is exceedingly unfavorable to a group which was seldom able to work in the critical period. ${ }^{46}$

of preference of a 35-year old arrangement under which road service engineers had been entitled to preference over yard service engineers in bidding for the job of operating a certain train. The court held that (p. 457) "where the statutory representative makes contracts of the sort here involved having unfavorable effects upon some members of the craft who present a grievance on that account, it is the Adjustment Board which has jurisdiction of the controversy, and not the courts...." The Steele and Howard cases were distinguished on the ground that (p. 456) "both those cases dealt with racial discrimination." For a somewhat similar ruling see Colbert v. Brotherhood of Railroad Trainmen, 206 F.2d 9 (9th Cir. 1953), cert. denied, 346 U.S. 931, rehearing denied, 347 U.S. 924 (1954). Even where it rests on the ground that plaintiffs had an administrative remedy, the Spires opinion seems out of line with later decisions. See pp. 169-175 infra.

43. Ford Motor Co. v. Huffman, 345 U.S. 330, 337 (1953) ; Mount v. Grand International Brotherhood of Locomotive Engineers, 226 F.2d 604 (6th Cir. 1955); Hughes Tool Co. v. NLRB, 147 F.2d 69. (5th Cir. 1945) ; Hargrove v. Brotherhood of Locomotive Engineers, 116 F. Supp. 3 (D. D.C. 1953) ; Crowell v. Palmer, 134 Conn. 502, 58 A.2d 729 (1948) ; Brotherhood of Railroad 'Trainmen v. Luckie, 286 S.W.2d 712 (Tex. Civ. App. 1955); see also Brotherhood of Railroad Trainmen v. Howard, 343 U.S. 768, 775-776 (1951) (dissenting opinion of Vinson, C.J., Reed and Minton JJ.) ; Trailmobile Co. v. Whirls, 331 U.S. 40, 50-51, 62, 68-69 (1946) (dissenting opinion of Frankfurter and Jackson, JJ.).

44. Goodin v. Clinchfield R.R., 229 F.2d 578 (6th Cir. 1956), affirming, 125 F. Supp. 441 (E.D. Tenn. 1954) ; McMullans v. Kansas, O. \& G. R.R., 229 F.2d 50 (10th Cir. 1956) ; Flowers v. Locomotive Firemen, 212 Ga. 142, 91 S.E.2d 41 (1956); Lamon v. Georgia, S. \& F.R.R., 212 Ga. 63, 90 S.E.2d 658 (1955).

45. Crowell v. Palmer, 134 Conn. 502, 58 A.2d 729 (1948).

46. Foster v. General Motors Corp., 191 F.2d 907 (7th Cir. 1951) ; Doherty v. General Motors Corp., 176 F.2d 561 (3d Cir. 1949) ; cf. Monticue v. Baltimore \& O.R.R., 91 F. Supp. 561 (N.D. Ohio 1950) ; Cushnier v. Ford Motor Co., 89 F. Supp. 491 (E.D. Mich. 1950) (both holding that no unlawful discrimination against veterans resulted from measuring eligibility for an extra week's vacation by years of active 
Considerable litigation has resulted from the negotiation of collective agreements changing the relative seniority rights of different classes of employees within one bargaining unit. Seniority is not a property right even though it exists by long established custom and governs not only layoffs but promotions and other job opportunities. Seniority rights are created by contract and theoretically terminate when the contract expires. For the same reason the parties to the original contract may discharge or amend it by mutual consent, thereby altering the relative seniority rights of individual employees; but in negotiating the new agreement the union is subject to the duty of fair representation and its validity may be attacked on the ground that the agreement resulted from a breach of the fiduciary obligation.

In deciding whether a change in seniority arrangements involves fundamental unfairness, the courts have allowed wide latitude for the give-and-take of collective bargaining and majority rule. There is no unfairness in modifying a contract during a serious depression so as to require an employer to lay off married women before men; ${ }^{\mathbf{4 7}}$ such a rule is roughly calculated to increase the likelihood that there will be one breadwinner in every family. Shop stewards and other union officials may be given top seniority in layoffs because the preference may reasonably be thought to preserve stability in union affairs and produce more experienced handling of grievances and contract negotiations, ${ }^{48}$ but one wonders whether the same preference is lawful in making transfers or promotions. ${ }^{49}$ In the light of contemporary usage it is not unreasonable to give veterans credit for their military service even though they have not previously worked for the employer. ${ }^{\text {so }}$ Other cases sustain collective agreements merging two seniority districts into one unit ${ }^{\mathbf{5 1}}$ or splitting a large district into smaller units. ${ }^{\mathbf{2}}$ The merger of two companies like the consolidation of once-separate operations into a single plant often gives rise to sharp conflicts of interest in working out the relative seniority rights of the two onceseparate groups of employees, but the courts have invariably-and

service in the plant). There may be a violation, however, if the base was selected for the purpose of discriminating against veterans. Alvado v. General Motors Corp., 229 F.2d 408 (2d Cir. 1956).

47. Hartley v. Brotherhood of R.R. and S.S. Clerks, 283 Mich. 201, 277 N.W. 885 (1936).

48. Aeronautical Lodge v. Campbell, 337 U.S. 521 (1949).

49. Cf. Glenn L. Martin Co., 19 War Lab. Rep. 263 (1944).

50. Ford Motor Co. v. Huffman, 345 U.S. 330 (1953) ; Haynes v. United Chemical Workers, 190 Tenn. 165, 228 S.W.2d 101 (1950).

51. Colbert v. Brotherhood of Railroad Trainmen, 206 F.2d 9 (9th Cir. 1953). The value of the opinion is reduced by the court's erroneous assumption that the Steele doctrine is largely limited to problems of racial discrimination.

52. Napier v. System Federation No. 91, 127 F. Supp. 874 (W.D. Ky. 1955). 
wisely-refused to become entangled in the merits of a conscientiously negotiated solution. ${ }^{53}$

The most puzzling of these cases arose out of a series of transactions by which Trailmobile Company absorbed its wholly owned subsidiary, Highland Body Mfg. Company, and consolidated in the Trailmobile plant operations theretofore performed at two separate locations. The employees at each plant were represented by their own AFL local union, but Trailmobile was the larger and its employees outnumbered Highland's employees ten to one. After the consolidation was under way a question arose concerning the seniority of Highland's employees in the Trailmobile plant. AFL ruled that the two onceseparate lists should be dovetailed by measuring the seniority of every employee in the consolidated unit from the date of first employment by either company. The Trailmobile employees were discontented; their self-interest would be served by putting the Highland employees at the bottom of the list on the theory that seniority ran from the date of first employment by the Trailmobile Company. They formed a CIO union, secured an NLRB election covering both groups ${ }^{54}$ won the election ${ }^{55}$ and then induced Trailmobile to execute a collective agreement changing the seniority system to put the Highland employees at the bottom of the list. The minority attacked the new arrangement in a series of law suits. The first was dismissed by an Ohio state court prior to Steele v. Louisville \& N.R.R. without considering the CIO union's fiduciary obligations. ${ }^{86}$ In a later suit under the Selective Service Act the Supreme Court held that the fairness of the conduct of the bargaining representative was not subject to attack by the veteran in such an action. ${ }^{57}$ Justices Frankfurter and Jackson, who dissented from the decision, expressed the view that the seniority rights of the Highland employees under the initial arrangement had "never been terminated or modified by good faith collective bargaining in the interests of the craft," 58 and consequently they would have invalidated the CIO contract for breach of the duty of fair representation. This issue was squarely raised by a later suit but the Sixth Circuit sustained the union.

53. Walker v. Pennsylvania-Reading Seashore Lines, 142 N.J.Eq. 588, 61 A.2d 453 (1948); Leeder v. Cities Service Oil Co., 199 Okla. 618, 198 P.2d 198 (1948); $c f$. Holman v. Industrial Stamping and Mfg. Co., 344 Mich. 235,74 N.W.2d 322 (1955).

54. The Trailer Co., 51 N.L.R.B. 1106 (1943).

55. The Trailer Co., 53 N.L.R.B. 1248 (1943).

56. Hess v. Trailer Co., 31 Ohio Op. 566 (1944).

57. Trailmobile Co. v. Whirls, 331 U.S. 40 (1947).

58. Id. at 62,69 . 
"Whatever we might think of the fairness of the differentiation, the discrimination was in pursuance of the bargaining process and not without some basis, forestalled a strike and was therefore not invalid." ${ }^{59}$

This ruling might be sound if the seniority arrangements detrimental to the Highland employees had been conscientiously worked out in an effort to find the fairest and most practical solution to the puzzling problems resulting from the consolidation. Although dovetailing is often preferred on the theory that both groups contribute work to the consolidated operation and should, therefore, share proportionately in future job opportunities, the practice is not a universal one and there may be something to be said for giving employees in the much larger plant priority where it is the unit into which the onceseparate operations are merged. In such a case laying off the employees from the smaller plant at a time of cutbacks in production is not much different from what would have occurred if the physical operations had been kept separate and the smaller plant was shut down when production was curtailed. Perhaps there is also rough justice in following the forms of the intercorporate transaction. A merger might support dovetailing while a purchase of assets and liquidation of the subsidiary would justify measuring seniority from the date of first employment by the corporate entity which survived. In the Trailmobile situation, however, the AFL parent organization had already determined that dovetailing was the fairest solution. Since the subsequent change was accomplished by votes and economic power, it is difficult not to say, with Justices Frankfurter and Jackson, that the seniority rights of the minority "were simply misappropriated to the benefit of the majority group." Any equity in the circuit court's ruling appears to rest on the practical view that "to the lion belongs the lion's share."

Other courts have indicated that the duty of fair representation prohibits the majority from changing seniority rosters simply for the purpose of appropriating job opportunities theretofore enjoyed by the minority. In Hargrove v. Brotherhood of Locomotive Engineers, ${ }^{60}$ the plaintiffs had worked within the Oak Ridge Atomic Energy Reservation first for the construction companies but later for the L. \& N. Railroad under a collective bargaining agreement which established a seniority roster giving the plaintiffs preference on work within (1950).

59. Britt v. Trailmobile Co., 179 F.2d 569 (6th Cir.), cert. denied, 340 U.S. 820

60. 116 F. Supp. 3 (D.D.C. 1953). 
the reservation but denying them any rights on other railroad property. After three years the union and the L. \& N. cancelled this agreement and entered into new contracts bringing the Oak Ridge operations under the seniority system applicable to the entire Knoxville and Atlanta division. The change gave engineers and firemen on the Knoxville and Atlanta division seniority rights on work within the reservation. Many of the plaintiffs lost their employment. A motion to dismiss the complaint was denied because "the discriminations based on prior employment and geography alone are also irrelevant and invidious." ${ }^{11}$ Brotherhood of Railroad Trainmen v. Luckie, ${ }^{62}$ affirmed an order enjoining the common bargaining representatives of train crews of two separate railroads from assigning the employees of one road the right to operate a passenger train of the other thereby reducing the work available to the latter's employees in order to compensate the former group for jobs lost through their employer's discontinuance of passenger service. ${ }^{\text {s }}$

Such decisions have much to commend them. From a practical standpoint seniority confers a status more important than a bare contractual undertaking. In practice seniority clauses are usually carried forward from year to year. Contract and custom create expectations. Expectations create reliance. It is scarcely an exaggeration to say that in some industries, notably railroads, employees build their lives upon seniority preferences in bidding for jobs in a defined pool of work. Under these circumstances it seems highly formal to reason that since the union and company negotiated the original seniority clause, they can change it at will. When established seniority rights are changed, the bargaining representative should be required to show some practical justification beyond the desire of the majority to share the job opportunities theretofore enjoyed by a smaller group. ${ }^{64}$

61. $I d$. at 8 .

62. 286 S.W.2d 712 (Tex. Civ. App. 1955).

63. See also Mount v. Grand International Brotherhood of Locomotive Engineers, 226 F.2d 604 (6th Cir. 1955); Belanger v. Local Division No. 1128, 254 Wisc. 344, 36 N.W.2d 414 (1949); cf. Piercy v. Louisville \& N.R.R., 198 Ky. 477, 248 S.W' 1042 (1923).

64. In Belanger v. Local Division No. 1128, 254 Wisc. 344, 354, 36 N.W.2d 414, 419 (1949), it was suggested that an amendment must be justified by changed economic conditions. This criterion is probably too narrow because it excludes changes of the kind which occur as an employer yields to a union's pressure for "improvement" of the collective bargaining agreement-for example, the gradual enlargement of seniority classifications in an effort to achieve plant-wide seniority. In Langhurst v. Pittsburgh \& Lake Erie R.R., 81 Pa. D. \& C. 513, 515 (C.P., Ally. 1949), the court refused to enjoin a merger of seniority districts negotiated "for economic reasons which are not stated in the complaint and which are not material to the action of this case." I question the statement that the economic reasons were not material to the merits of the action. 
There is also danger of "misappropriation" in the adjustment of money claims under existing contracts. In Jennings $v$. Jennings, ${ }^{65}$ the complainants alleged the following facts:

In 1943 the basic steel companies and various labor unions embarked on a program for job valuation and the establishment of standard earning rates which would eliminate many intra-plant inequities in the wage structure. The program covered several years. On July 21, 1947, Truscon Steel Company and the International Association of Machinists entered into a collective bargaining agreement which provided: (1) that the new standard rates should be put into effect as of April 1, 1947, and any employee whose rate was established after that date should be paid retroactively the difference between his actual earnings and what his earnings would have been at the standard hourly rate; and (2) that all employees who had suffered wage rate inequities from December 23, 1943, to March 31, 1947, should receive individual "lump sum" payments covering the amounts which they would have been paid if the job had been properly rated, to be disbursed "in accordance with an understanding to be reached between the company and the union,". provided that the employer's total liability for the period December 23, 1943, to March 31, 1947, should not exceed $35 / 8$ cents times the total number of man hours worked by all its employees during that period. Late in 1947 retroactive application of the standard rates revealed that the union members suffered the least inequities and that a small group of employees, most of whom were not members of the union, had suffered large inequities. The union members thereupon voted that the lump sum due each employee for the period prior to March 31, 1947, should be calculated at the uniform rate of $35 / 8$ cents per hour for each employee without reference to individual inequities determined according to the new standard earning rates. Truscon agreed. The Ohio Court of Appeals affirmed a judgment sustaining a demurrer to the bill of complaint, saying:

"By such majority action, each person represented shared in the fund; though it appears not in accordance with the sense of justice nor fairness to each such person.

"Since such fund was created within the legal scope of the union's activities as exclusive bargaining agent, the majority of its members . . . possessed authority to control the agent's action as to the distribution of such fund. Accordingly, in the absence of collusion or discrimination amounting to fraud . . . resort to a court of equity cannot be had against the legal action of a

65. 91 N.E.2d 899 (Ohio App. 1948). 
majority, no matter how mistaken or oppressive from a minority viewpoint such majority action may be." 66

The Jennings decision appears to rest upon a misconception of the Steele doctrine. The duty of fair representation limits majority rule for the very purpose of preventing conduct "oppressive from a minority viewpoint" and "not in accordance with the sense of justice nor fairness to each such person." To argue that the bargaining representative may take from employees retroactively any benefits which it negotiated both overlooks the individual expectations and reliance built up by a contract and also assumes that the initial contractual arrangement was based upon an arbitrary judgment rather than the dictates of fairness and practicality. Nor was the court required to decide for itself whether it was fair to make a per capita distribution of the fund. The company and union had already agreed that the standard earning rates supplied a fair measure for each employee's compensation not only in the future but also for retroactive pay between April 1 and July 1, 1947. They had already agreed abstractly that the same measure would be just in correcting prior inequities and apparently the majority of the union members overturned the initial arrangement only because they found that the measure which they had agreed was fair would not yield them as much money as a group of nonmembers. Thus, the representation which the union accorded the plaintiffs was unfair when judged by the standards of fairness the union itself had joined in establishing. It is submitted that in the absence of supervening events justifying a rearrangement this proof was enough to warrant a judgment for the plaintiffs. ${ }^{67}$

\section{V.}

\section{Standards of FaIRness. ${ }^{68}$}

Although collective bargaining developed as a method of resolving conflicts of interest between an employer and employees, it also serves

66. Id. at 902 .

67. Possibly the Jennings decision can be supported on the ground that the retroactive pay for the period prior to March 31, 1947, was a windfall in the sense that the employees rendered services during that period without assurance that they would receive compensation in addition to the rates then prevailing. The representative's "legislative power" in dealing with a windfall is probably greater than its power to disturb vested rights acquired in reliance upon an existing condition. See pp. 159-164 infra. The latter problem would have been presented in the Jennings case if the 1948 agreement had also modified the retroactive pay due for the period between March 31, 1947, and the establishment of standard earning rates. The explanation seems hardly adequate, however, partly because the institution of the job evaluation program of 1943 gave rise to some expectation of additional pay for work done after that date and partly because some degree of fairness should be required even in dealing with windfalls.

68. See also Duty of Union to Minority Groups in the Bargaining Unit, 65 Harv. L. REv. $490 \cdot(1952)$. 
the additional function of adjusting the interests of competing groups of employees within the same bargaining unit. The needs and wants of individuals differ even in a homogeneous craft unit. In plant-wide, multi-plant or multi-employer units the divergencies and opportunities for conflict are even greater, and the negotiation and administration of the collective agreement involves repeated efforts to reconcile differences or else determine whose interests should be preserved.

Too strict judicial or administrative supervision through the concept of fair representation would impair the flexibility and adaptability of collective bargaining while substituting governmental decisions for self-determination. Past experience with judicial intervention in labor relations gives little reason to suppose that the judges' decisions would be wiser than negotiated settlements. On the other hand, so long as numerical majorities occasionally yield to selfishness or caprice, there will be somewhat the same need for judicial or administrative checks on majority rule in collective bargaining as there is for judicial review of legislative enactments. Whether courts and agencies steer a safe central course between the opposing dangers will probably depend upon their success in developing standards of "fairness."

The Constitution affords one source of guidance. The bargaining representative has "at least as exacting a duty to represent equally the interests of the member of the craft [i.e., the unit] as the Constitution imposes upon a legislature to give equal protection to the interests of those for whom it legislates." 69 The reference supplies a clear-cut test in situations involving racial discrimination ${ }^{70}$ but in other cases it suggests only the mood of approaching the necessary judgment.

Statutory policies may occasionally measure what is "fair." The Railway Labor Act and the National Labor Relations Act embrace the policy of assuring employees full freedom of choice in selecting bargaining representatives. For a union to differentiate between members and nonmembers in negotiating a contract ${ }^{71}$ or handling grievances is "unfair" because it runs counter to the statutory policy unless justified

69. Steele v. Louisville \& N.R.R., 323 U.S. 192, 202 (1944).

70. The use of the constitutional standard is reflected in such cases as Pellicer v. Brotherhood of Railway and S.S. Clerks, 217 F.2d 205 (5th Cir. 1954), cert. denied, 349 U.S. 912 (1955), where the court dismissed a complaint filed by white employees against the bargaining representative on the theory that the union had not granted equal representation to all the employees in the bargaining unit when it negotiated a seniority arrangement which removed a previous discrimination against Negroes, saying: ". . . the amendment to the bargaining agreement did not amount to discrimination against the white employees but merely rectified an existing discrimination against the colored employees, the effect of which as to the former was damnum absque injuria."

71. Cf. Wallace Corp. v. NLRB, 323 U.S. 248 (1944); NLRB. v. Gaynor News Co., 197 F.2d 719, 722 (2d Cir. 1952), affirmed, 347 U.S. 17 (1954). 
by a valid union shop agreement. ${ }^{72}$ Under the NLRA the discrimination is an unfair labor practice if it affects hire, tenure or terms or conditions of employment ${ }^{73}$ but under the RLA the employees' only remedy is a private suit for violation of the union's duty as bargaining representative. ${ }^{74}$ Conversely, the statutory preferences granted veterans in public employment were given weight in upholding a collective bargaining agreement which gave veterans in private employment a seniority rating based partly upon military service. ${ }^{75}$

A judgment of "fairness," in any context, also depends partly upon finding the actor's motivation, partly upon reason and partly upon conformity to accepted norms. Industrial and collective bargaining practice will, therefore, shed considerable light on the fairness of particular contracts, and a court should hesitate to invalidate a negotiated solution of a kind which has gained a measure of acceptance in other bargaining units. Conversely, a sudden reversal of an established practice may require affirmative justification not only because it defeats the expectations of individual employees but also because general acceptance of the prior arrangement showed it to be prima facie fair and reasonable. ${ }^{78}$ Beyond this, however, guides must be found in the moral standards of the industrial world and the precepts of the community. Doubts should be resolved in favor of collective bargaining unless the minority claims infringement of civil liberties.

Applying the duty of fair representation to the settlement of grievances involves the most difficult inquiries. ${ }^{77}$ Where the sum is plainly due, the collective bargaining representative should have no power to waive or compromise the claim of one group of employees in return for a concession supposed to benefit a larger number. Such dickering in vested rights is simply taking money from one group to give to another. Even a legislature has no power thus to redistribute the wealth. ${ }^{78}$ In constitutional law, however, the rule is not absolute. The courts sustained the provisions of the Portal-to-Portal Act which wiped out vested employee claims for past wages potentially totaling

72. Hughes Tool Co. v. NLRB, 147 F.2d 69 (5th Cir. 1945); Crowell v. Palmer, 134 Conn. 502, 58 A.2d 729 (1948).

73. National Labor Relations Act $\$ \S 8(a)(3), 8(b)(2), 61$ SrAT. 140, 141 (1947), as amended, 29 U.S.C. $\$ \$ 158$ (a) (3), 158(b) (2) (1952); e.g., Radio Officers Union v. NLRB, 347 U.S. 17 (1954).

74. Crowell v. Palmer, 134 Conn. 502, 58 A.2d 729 (1948).

75. Ford motor Co. v. Huffman, 345 U.S. 330 (1953).

76. See pp. 159-164 supra.

77. The problems discussed in this paragraph arise only if the bargaining representative has statutory or contractual power to bind individual employees by the adjustment of a grievance. See Cox, Rights Under a Collective Agreement, 69 Harv. L. REv. 601 (1956).

78. See Thompson v. Consolidated Gas Util. Corp., 300 U.S. 55 (1937). 
many million dollars. ${ }^{79}$ Part of the justification for the qualification was the fallacy in our conventional assumption that a legal claim is either valid or invalid once the events have passed, because existing law covers every point and every instrument has a fixed meaning. In truth, the adjudication of disputable claims may involve a large measure of law-making, and the interpretation of contracts often requires supplying a "fictitious" intent in order to provide a rule for a situation the parties did not envisage. The repercussions of the new law may reach beyond the immediate parties to the surrounding community, where the impact may be more important than the private quarrel. In the Portal-to-Portal Act cases, moreover, the employees' claims were an unexpected windfall. No one could be supposed to have worked in reliance upon a right to pay for travel time not established by contract or usage or to have altered his position when the claim was called to his attention.

Might not similar criteria be applied to the compromise of grievances by a bargaining representative? Where the intent of the collective agreement is to give only rights which can be enforced and compromised by the union, the adjustment should be binding unless the compromise arbitrarily gives away the "property" (i.e., the claim to compensation or damages) of the individual worker. In judging whether the compromise is "unfair" one should take into account the fact that negotiation of the collective contract was the result of a group endeavor, and also such other circumstances as the merits of the claim, the effect upon other employees, the future implications of the settlement, and any evidence of discrimination or arbitrary "horse trading."

VI.

REMEDIES.

A.

Jurisdiction.

Railway Labor Act.

The Railway Labor Act provides no administrative remedy for violation of the duty of fair representation except possibly in cases where the unfairness occurred in the administration of a collective bargaining agreement; ${ }^{80}$ and it is silent with respect to judicial pro-

79. 61 STAт. 84 (1947), 29 U.S.C. \$\$251-62 (1952); see, e.g., Battaglia v. General Motors Corp., 169 F.2d 254 (2d Cir.), cert. denied, 355 U.S. 887 (1948).

80. In the latter instance the employee may be able to invoke the services of the National Railway Adjustment Board. Railway Labor Act § 3, 48 STAT. 1189 (1934), 45 U.S.C. § 153 (1952). 
ceedings. Once a legal obligation was implied, however, the issue became fairly comparable to the problems raised by a carrier's unlawful interference with the employees' choice of representatives or its refusal to treat with the designated representative and exert reasonable efforts to negotiate an agreement. Although the statute provided no sanction, the courts supplied judicial remedies. ${ }^{81}$ In the Steele case the Supreme Court followed the analogy and ruled "that the duty which the statute imposes on a union representative of a craft to represent the interests of all its members stands on no different footing and that the statute contemplates resort to the usual judicial remedies of injunction and award of damages. . . ." 82 The employer should be joined as a co-defendant whenever it participated in the agreement or course of conduct under attack.

Since the employees are asserting a federal right arising under a law regulating commerce, the action may be brought in a federal district court without diversity of citizenship and regardless of the amount in controversy. ${ }^{83}$ Alternatively, the employees may sue in a state court of general jurisdiction and take any federal question to the Supreme Court of the United States either by certiorari or in appropriate cases by appeal..$^{84}$

A few inferior courts have continued to dismiss actions to enforce the right of fair representation, despite the Steele decision, upon the ground that the plaintiffs failed to exhaust their administrative remedies before the National Railway Adjustment Board. ${ }^{85}$ These decisions must be regarded as "plainly wrong" insofar as the employees were complaining of discrimination either in the making of a collective bargaining agreement or in the development of customs, rules and other informal arrangements fixing terms and conditions of employment, for the adjustment boards have no jurisdiction unless there is a dispute "growing out of grievances or out of the interpretation or application of agreements concerning rates of pay, rules, or working conditions." 86

81. Virginian R.R. v. System Federation No. 40, 300 U.S. 515 (1937); Texas \& N.O.R.R. v. Brotherhood of Railway and S.S. Clerks, 281 U.S. 548 (1930).

82. Steele v. Louisville \& N.R.R., 323 U.S. 192, 207 (1944).

83. Graham v. Brotherhood of Locomotive Firemen \& Enginemen, 338 U.S. 232 (1949) ; Tunstall v. Brotherhood of Locomotive Firemen \& Enginemen, 323 U.S. 210 (1944).

84. Steele v. Louisville \& N.R.R., 323 U.S. 192 (1944).

85. E.g. Richardson v. Texas \& N.O.R.R., 140 F. Supp. 215 (S.D. Tex. 1956) ; Conley v. Gibson, 138 F. Supp. 60 (S.D. Tex. 1955), affirmed, 229 F.2d 436 (5th Cir. 1956), cert. granted, 77 Sup. Ct. 37.

86. Railway Labor Act § 3, First (i), 48 Star. 1191 (1934), 45 U.S.C. $\$ 153$, First (i) (1952); accord, Brotherhood of Railroad Trainmen v. Howard, 343 U.S. 768, 774 (1952); Mount v. Grand International Brotherhood of Locomotive Engineers, 
The problem is more difficult when the alleged breach of duty occurs in the administration of a collective bargaining agreement. In Hayes v. Union Pacific R.R. ${ }^{87}$ a collective bargaining agreement covering dining car employees established four seniority groups according to the type of train. Each group contained several seniority classes such as chef-caterer, chef, second cooks, etc. When a vacancy occurred in a higher classification employees bid for promotion, and the contract provided that seniority should control when fitness and ability were sufficient. Although the contract was neither discriminatory on its face nor established grounds for discrimination, a group of Negro dining car employees brought an action in a federal district court against their bargaining representative and the carrier alleging that Negroes were systematically excluded from the top two classifications without regard to fitness or ability and in disregard of their seniority over white employees who were promoted. The truth of the allegation was admitted by a motion to dismiss but the district judge held there was no federal jurisdiction because the cause of action, if any, was based upon breach of the agreement and did not arise in its making. The Court of Appeals for the Ninth Circuit affirmed. ${ }^{88}$

The decision is highly questionable. As a general rule individual employees should not be allowed to circumvent the forum the adjustment boards provide for grievances arising out of breach of a collective bargaining agreement merely by alleging violation of the statutory duty of fair representation, but under the circumstances of the Hayes case this remedy was hardly adequate. The adjustment boards apparently refuse to hear complaints filed by individual members of a craft represented by a labor organization. Where the real wrong is systematic exclusion from preferred jobs, a series of individual complaints is cumbersome and expensive. The adjustment boards are composed of equal numbers of representatives of carriers and railway labor unions. To remit the minority to their oppressors for justice would be an empty fraud, as Mr. Chief Justice Stone explicitly recognized in Steele v. Louisville \& Nashville R.R. ${ }^{89}$ Moreover, while the relief obtainable from an adjustment board is not limited to an award of damages, its decision could not go beyond the existing contract and

226 F.2d 604 (6th Cir. 1955) ; Hargrove v. Brotherhood of Locomotive Engineers, 116 F. Supp. 3 (D. D.C. 1953) ; Brotherhood of R.R. Trainmen v. Luckie, 286 S.W.2d 712 (Tex. Civ. App. 1955).

87. 88 F. Supp. 108 (N.D. Cal. 1950).

88. 184 F.2d 337 (9th Cir. 1950). In Dillard v. Chesapeake \& O.R.R., 199 F.2d 948, 951 (4th Cir. 1952), the court refused to follow the Hayes case on the ground that it was inconsistent with Brotherhood of Railroad Trainmen v. Howard, 343 U.S. 768 (1952).

89. 323 U.S. 192, 206 (1944). 
even if it were favorable to the plaintiffs, they would be required to commence a new search for relief whenever the carrier and union modified the agreement. Nor is it an answer to say that the Hayes decision may permit an action based on the contract in a state court without the necessity of exhausting the adjustment board procedure. A suit for breach of contract might well fail upon the ground that the contract had been effectively modified by the uniform practice in which the carrier and bargaining representative joined. Even if the action could be maintained, however, there is no rule which would force the plaintiffs to bring a state court action on the contract instead of suing for breach of a duty imposed by the RLA.

National Labor Relations Act.

It is not yet clear whether the relief against breach of the duty of fair representation by a union subject to the NLRA is to be obtained by private action or in unfair labor practice proceedings. Section 8 (b) (3) makes it an unfair labor practice for a union "to refuse to bargain collectively with an employer, provided it is the representative of his employees subject to the provisions of section 9(a)."

Section $8(d)$ provides in part:

"to bargain collectively is the performance of the mutual obligation of the employer and the representative of the employees to meet at reasonable times and confer in good faith with respect to wages, hours and other terms and conditions of employment. . . ."

The critical inquiry would seem to be whether section 8(b) (3) should be construed: (1) to regulate only the union's conduct in relation to the employer, or (2) to embody all its statutory obligations in negotiating or administering an agreement as the employees' exclusive representative. The former interpretation leaves room for judicial remedies for breach of the duty of fair representation. The latter makes breach of the duty an unfair labor practice over which the NLRB would have exclusive jurisdiction.

The statutory language hardly answers the question, although the reference to "the mutual obligation of the employer and the representative of the employees" suggests that other duties are excluded. "To bargain collectively with an employer" may imply bargaining fairly on behalf of all the employees. The legislative history is not revealing. The committee reports and debates contain no references to the Steele doctrine even though it was widely known when the Taft-Hartley amendments were under consideration. Four considerations make it 
plausible to suppose, however, that a congressman who was sympathetic to the policies of the amended act, who intended to impose a duty of fair representation and who foresaw the present issue, would have made breach of the duty an unfair labor practice remediable by the NLRB :

(1) Breach of any other obligation imposed by the NLRA, upon employer or bargaining representative, is an unfair labor practice. This is true of the general duty to bargain collectively. There was no reason for making a single narrow exception to the general policy of reliance upon administrative proceedings.

(2) Although the issues are usually distinct, separating the issues raised by a single course of bargaining may be so artificial as to produce gaps or conflict and inconsistency. For example, whether an employer has violated his duty to bargain in good faith may depend upon whether the union's proposals violate its obligation to employees in the bargaining unit. ${ }^{90}$

(3) Even though the legal issues may sometimes have the broad character of constitutional questions familiar to the courts, the administrative process offers several advantages similar to its values in familiar unfair labor practice cases. Persons thoroughly familiar with industrial practices may be a little wiser in appraising the evidence, in applying general standards and even in pricking out new generalizations-new law-for future cases. Precedents are easier to distinguish and even to overrule. Problems can sometimes be solved more easily by conference and compromise prior to formal proceedings. A single agency is better equipped than scattered judges to project the development of standards of fair representation which will protect minorities without constricting normal negotiations.

(4) The General Counsel prosecutes complaints of unfair labor practices because of the general public interest in effectuating the national labor policy. The public welfare equally requires action to prevent unions from using their statutory powers in order to gain unfair advantage for a dominant faction. Private suits are not an effective sanction unless financed by an organized group. Individual victims of unfair bargaining seldom obtain the skilled legal assistance necessary to bring litigation to a successful conclusion in a novel field of law.

In my opinion, therefore, breach of the duty to bargain fairly should be held an unfair labor practice. The point is open, but four opposing circumstances ought to be kept in mind by anyone seeking to

90. Times Publishing Co., 72 N.L.R.B. 676 (1947). 
predict the actual course of decision. (1) A considerable body of precedent has already grown up in suits under the Railway Labor Act where there is no administrative remedy. (2) In actions under the Selective Service Act the Supreme Court has discussed whether there was a breach of the duty of fair representation without considering whether a violation would not have been an unfair labor practice within the NLRB's exclusive jurisdiction. ${ }^{91}$ (3) In the Syres case the employees brought a private suit and the Supreme Court reversed a judgment dismissing the complaint; possibly the order decides the present issue. $^{82}$ (4) The NLRB has never asserted such jurisdiction. In short, the issue seems likely to go by default unless pressed more vigorously upon an early occasion.

A second alternative to a private suit is to ask the NLRB to withdraw the union's certification. The Board has repeatedly asserted,

91. Ford Motor Co. v. Huffman, 345 U.S. 330 (1953) ; Aeronautical Lodge v. Campbell, 337 U.S. 521 (1949). There are two cases somewhat closer to the point which may hold that the NLRB remedy is exclusive. Holman v. Industrial Stamping and $\mathrm{Mfg}$. Co., $142 \mathrm{~F}$. Supp. 215 (E.D. Mich. 1946) ; Holman v. Industrial Stamping and Mfg. Co., 344 Mich. 235, 74 N.W.2d 322 (1955). The plaintiff in these cases was seeking to challenge the impairment of their seniority standing which resulted from a consolidation of two plants, followed by a change in the bargaining representative and the negotiation of a new contract. Both actions appear to have been based upon the theory that the union violated its duty of fair representation. Plaintiffs also filed unfair labor practice charges with the National Labor Relations Board. Its regional director dismissed the charges on the ground that there was no unfair labor practice. The dismissal was only a ruling that there was no violation of section 8 (b) ; it was not a ruling that there was no breach of the duty of fair representation because the NLRB does not regard a breach of this duty as a union unfair labor practice. The Supreme Court of Michigan dismissed the complaint on the ground that the federal act pre-empted the field citing Garner v. Teamsters Union, 346 U.S. 485 (1953). It is submitted that this analysis confused two different issues: (1) whether federal substantive law applied to the exclusion of state law and (2) whether breach of the duty of fair representation gives rise to a private action or an unfair labor practice. The Supreme Court of Michigan was quite correct in holding that federal law applied but it neglected to consider whether the remedy was before the NLRB or by private action.

In the district court action the court said: "A collective bargaining agent certified by the National Labor Relations Board is authorized to negotiate questions of seniority. ... If defendants ... have discriminated against plaintiffs, as alleged in this action, the National Labor Relations Act, as amended, affords the plaintiffs the right to seek relief before the National Labor Relations Board." Possibly this is a square ruling that breach of the duty of fair representation is an unfair labor practice. So long as the General Counsel operates on a different theory, however, individual employees are in the curious position of having no method of compelling him to change his view yet being denied relief in a private action on the ground that the NLRB affords a remedy.

92. Syres v. Oil Workers International Union, 350 U.S. 892 (1955), reversing, 223 F.2d 739 (5th Cir. 1955). In the district court defendants moved to dismiss the complaint upon several grounds including: (1) the failure to state a cause of action within the jurisdiction of the district court; and (2) the failure to exhaust the administrative remedy. The district court dismissed the complaint and the Court of Appeals for the Fifth Circuit affirmed on the ground that the union's only duty arose from the plaintiffs' consensual grant of agency powers. See pp. 154, 155 supra. Since the circuit court held there was no statutory duty, it did not consider whether the remedy for breach of such a duty, if it did exist, would be judicial or administrative. Since the Supreme Court reversed the circuit court without delivering an opinion or even hearing argument on the merits, there is no way of knowing whether the case is only a precedent for the principle that there is a statutory duty enforceable in a proper proceeding or for the proposition that an action at law may be maintained in the federal court. 
but rarely exercised, the power to revoke the certification of any union which fails to represent minorities fairly. ${ }^{93}$ This remedy may offer some protection when the employer would like to withdraw recognition or where a rival union could oust the incumbent once the protection of the certification was withdrawn; but it would have no practical value in situations in which the incumbent union had never been certified or was able to negotiate discriminatory or oppressive contracts by virtue of the employer's cooperation or its own economic power. A failure to exhaust this inadequate administrative remedy should not bar an action for an injunction or damages.

B.

Injunctions.

The most effective remedy for breach of the duty of fair representation is an injunction forbidding the union and employer from carrying on the unlawful arrangement and requiring the union to bargain on behalf of all the employees in the future. Since damages are too speculative to constitute an adequate remedy at law, the complainants have a conventional basis for the chancellor's intervention.

The Norris-LaGuardia Act is not a bar to an injunction. It is also unnecessary for the court to follow the procedure and make the findings specified in the anti-injunction act. Both points are settled by precedent, even though the underlying controversy obviously falls under the statutory definition of a "labor dispute." While the result is justified by common sense, it is hard to work out an acceptable rationale. The Supreme Court first dealt with the point by bare assertion, ${ }^{94}$ as it had done in parallel situations involving the rights to organize and bargain collectively, ${ }^{95}$ and by adhering to the precedents because a departure lessening the protection available to employees "would indeed be to 'turn the blade inward." "96 Perhaps no more can be said than that the provisions, legislative discussions and historical background of the anti-injunction laws show that they have to do only with judicial interference with lockouts, strikes, boycotts and picketing. ${ }^{97}$

Few problems have arisen thus far in framing appropriate decrees. Where the violation culminates in a contract, the decree should de-

93. E.g., Larus \& Bro., 62 N.L.R.B. 1075 (1945). (1944).

94. Tunstall v. Brotherhood of Locomotive Firemen \& Enginemen, 323 U.S. 210

95. Virginian Ry. v. System Federation No. 40, 300 U.S. 515, 563 (1937).

96. Graham v. Brotherhood of Locomotive Firemen, 338 U.S. 232, 237 (1949); accord, Rolfes v. Dwellingham, 198 F.2d 591 (8th Cir. 1952).

97. Cf. Local 205, UERMWA v. General Electric Co., 233 F.2d 85 (1st Cir. 1956); Textile Workers Union v. American Thread, 113 F. Supp. 137 (D. Mass. 1953). 
clare its invalidity, enjoin its performance and forbid similar wrongdoing. Nearly all the adjudicated cases in which the union was held to have violated its duty involved contracts which altered pre-existing rights under an earlier agreement or established arrangement. In this situation it is appropriate for the court to require the union and the employer to restore the plaintiffs to their previous rights, subject to modification in future negotiations conducted in accordance with the statutory policy. In Central of Georgia Ry. $v$. Jones, ${ }^{98}$ the carrierdefendant had engaged in racial discrimination against the plaintiffs pursuant to a collective bargaining agreement negotiated by their statutory representative but the discrimination, so far as the evidence showed, long antedated the contract. The court enjoined the carrier and the union from enforcing the contract and "affirmatively required each to grant the same seniority rights, training privileges, assignments and opportunities to these jobs as white persons of similar continuous service would enjoy." The Fifth Circuit affirmed this decree without discussing the justification for requiring the carrier to remove discrimination which it would have been legally free to practice in the absence of collective bargaining. Circuit Judge Brown argued in dissent that the carrier was subject to no duty to eliminate discrimination although "the Brotherhood had, to be sure, the profound obligation fully and earnestly to bargain to prevent, and, where necessary, remove discriminations." ${ }^{99}$ The Brotherhood's statutory duty would seem to be limited to an obligation not to use its power to negotiate invidious distinctions and as pointed out above, ${ }^{100}$ it is hard to find a violation of the statute if a union simply refrains from negotiating about a carrier's seniority practices. On this theory Circuit Judge Brown may have conceded too much in assuming that the Brotherhood should be ordered to bargain for removal of the discrimination; a fortiori he was on sound ground in objecting to the order against the carrier. The only legal analysis which appears to be available to sustain the decree, however much one may applaud its social and economic consequences, is the doctrine that equity may impose more far-reaching restraints than the substantive law in order to redress past wrongs and prevent future infractions. ${ }^{101}$

98. 229 F.2d 648 (5th Cir. 1956), cert. denied, 77 Sup. Ct. 32, 57, cert. granted, 77 Sup. Ct. 90.

99. Id. at 650 .

100. See p. 157 supra.

101. Ethyl Gasoline Corp. v. United States, 309 U.S. 436 (1940) ; Warner \& Co. v. Lilly 265 U.S. 526 (1924); Triangle Publications, Inc. v. New England Publishing Co., 46 F. Supp. 198, 204 (D. Mass. 1942). 
At first blush equity's historic aversion to enforcing contracts for personal service might seem to be an obstacle to a decree ordering the reinstatement of an employee who was laid off or discharged by virtue of an unlawful contract. However, there is ample precedent for granting similar relief where the discharge violates the RLA, ${ }^{102}$ and NLRA section 10 (c) shows that Congress thought the ancient doctrine had no place in redressing unfair labor practices. ${ }^{103}$

C.

Damages.

The victims of a union's violation of the duty of fair representation may recover damages in an action at law or in equity as incidental relief. The precedents are too scattered to suggest the problems which may arise in measuring the damages but it seems likely that most can be answered by analogy to other instances of wrongful discharge. Where the unlawful contract attempted to alter pre-existing rights, the damages are measured by the difference between what plaintiff actually earned and what he would have earned under the prior agreement. ${ }^{104}$ Where the unlawful contract does not alter pre-existing rights, there is the same problem in determining whether the plaintiffs have actually suffered harm as there is in determining the form of an injunctive remedy, for no one can say whether there would have been unjust treatment in the absence of the collective bargaining agreement. ${ }^{105}$

102. Texas and N.O.R.R. v. Brotherhood of Railway and S.S. Clerks, 281 U.S. 548 (1930).

103. Cf. Phelps Dodge Corp. v. NLRB, 313 U.S. 177 (1941).

104. Rolax v. Atlantic Coast Line R.R., 186 F.2d 473 (4th Cir. 1951); Mitchell v. Gulf, Mobile and Ohio R.R. 91 F. Supp. 175, 187 (N.D. Ala. 1950), affirmed, 190 F.2d 308 (5th Cir. 1951).

105. See Central of Georgia Ry. v. Jones, 229 F.2d 648 (5th Cir. 1956), cert. denied, 77 Sup. Ct. 32, 57, cert. granted, 77 Sup. Ct. 90 . See also the discussion on pp. 175,176 supra. 